\title{
CHEMICAL COMPOSITION OF TUALANG HONEY AND ITS EFFECT ON THE LUNG SURFACTANTS AND HISTOLOGY OF MALE RATS EXPOSED TO CIGARETTE SMOKE
}

\author{
Chinedum Eleazu ${ }^{1,4}$, Aminah Che Romli ${ }^{1}$, Wan Faiziah Wan Abdul Rahman², Zaida Zakaria1 ${ }^{1}$ Zaidatul Akmal Othman ${ }^{1,5}$, Mahaneem \\ Mohamed ${ }^{1,3 *}$ \\ ${ }^{1}$ Department of Physiology, ${ }^{2}$ Department of Pathology, ${ }^{3}$ Unit of Integrative Medicine, School of Medical Sciences, Universiti Sains Malaysia, \\ 16150 Kubang Kerian, Kelantan, Malaysia, ${ }^{4}$ Department of Chemistry/Biochemistry and Molecular Biology, Alex Ekwueme Federal Univer- \\ sity Ndufu-Alike, Ikwo, Ebonyi State, Nigeria, ${ }^{5}$ Unit of Physiology, Faculty of Medicine, Universiti Sultan Zainal Abidin, 20400, Kuala Tereng- \\ ganu, Terengganu, Malaysia \\ *Corresponding author, E-mail: maheneem@usm.my
}

\begin{abstract}
This study reported the chemical composition of Tualang honey and its effect on the lung surfactants and histology of male rats exposed to cigarette smoke. Thirty-two adult male Sprague-Dawley rats were used and they were randomly divided into 4 groups of eight rats each: control, honey-treated (Honey), cigarette smoke-exposed (CS) and honey-treated plus CS (Honey+CS). Rats in control and CS groups received distilled water $(0.5 \mathrm{~mL} /$ day) while rats in Honey and Honey $+\mathrm{CS}$ groups received honey $(1.2 \mathrm{~g} / \mathrm{kg}$ body weight/day) by oral gavage. Furthermore, rats in CS and Honey+CS groups were exposed to CS in a chamber for 8 minutes (3 times/day). Exposure of rats to cigarette smoke significantly altered their phosphatidyl choline/ phosphatidyl glycerol (PC/PG) ratio but not their surfactant protein A levels with increased number of alveolar macrophage containing carbon particles. Administration of Tualang honey to CS exposed rats resulted in modulation of most of these parameters and which results were coroborrated by histology. The colour intenstity, $\mathrm{pH}$ and moisture content of the honey were obtained as 272.75 mili-absorbance unit, 3.43 and 17.38\%, respectively. Screening for phenolic compounds in Tualang honey using High Performance Thin Layer Chromatography showed the presence of 18 compounds while only five were identified which possessed strong in vitro antioxidant capacity as seen from their 2,2, diphenyl-1-picryl hydrazyl radical scavenging ability. The study showed the promising potentials of Tualung honey in protecting lung surfactants from the deleterious action of cigarette smoke which may be associated with its antioxidant phenolic compounds.
\end{abstract}

Key words: tualang honey; surfactant; inhalation toxicology; phenolic compounds

\section{Introduction}

Lung surfactant is a mixture of approximately $90 \%$ of phospholipids and $10 \%$ proteins (Sulfactant Proteins-A, B, C, and D) that are seen in the epithelial lining fluid in the internal surface of the lung alveoli $(1,2)$. Synthesis and release of these surfactants are important functions of type II pneumocytes (3). The normal production

Received: 15 October 2019

Accepted for publication: 13July 2020 of surfactant is necessary to maintain alveolar stability and lung function (4) including protection of the type II pneumocyte against oxidants (5). Therefore, the absence of lung surfactants results in the development of Respiratory Distress Syndrome, which is characterized by collapse of the alveoli and reduced gas exchange and an increased effort to breathe (2).

Cigarette smoking is one of the most pervasive habits that is practiced by several people in different countries of the world and which has been assoiated with several health risks such as 
lung cancers, heart disease, asthma, tuberculosis and others $(2,6,7,8)$. Previous reports have it that there are numerous cigarette smokers all over the world and cigarette smoking was reported to account for over 5 million deaths yearly world wide within the last decade (9). Furthermore, the chronic and insidious nature of smoking-related diseases can reduce the quality of life (10). It has been reported that tobacco smoke from cigarette interacts with the epithelial lining fluid (that contains antioxidants and lung surfactant) (2, 11, 12, 13). Through such interactions, the oxidants in tobacco smoke release free radicals and reactive oxygen species which can denature or degrade the components of the epithelial lining fluid, one of which is the lung surfactant. Furthermore, being that the epithelial lining fluid is thinner in the lower airways and alveoli, and contains lower concentration of antioxidants than the upper airways, damage from oxidants such as tobacco smoke also negatively affects the lung surfactants $(2,15)$.

Honey is a natural product that is produced by honeybees (Apis mellifera) from the nectar of flowers or from the secretions of living parts of plants $(15,16)$. Several health beneficial properties have been credited to it such as: antidiabetic (17, 18), anti-inflammatory (19), antibacterial (20), antioxidant $(21,22)$ and anticancer properties (23). In our previous study (22), we reported the protective effect of honey in cigarette smokeinduced testicular damage in rats. However, the action of honey on lung surfactants exposed to cigarette smoke has not been reported in humans or animals. This therefore led to this study which aimed at investigating the chemical composition of Tualang honey and its effects on the lung surfactant profiles and lung histology of male rats exposed to cigarette smoke.

\section{Materials and methods}

\section{Animal study}

Thirty-two adult male Sprague-Dawley rats weighing 270-320 g were used for this study and they were obtained from the Laboratory Animal Research Unit, Health Campus, Universiti Sains Malaysia and as such, permissions were not needed for the sampling. The study protocol was approved by the Animal Ethics Committee of the Universiti
Sains Malaysia (PPSG/07(A)/044/2007[32]) and the animals were handled in accordance with the Guide for the Care and Use of Laboratory Animals by National Institute of Health. The rats were kept in a polycarbonate cage, and were maintained on a 12 -h light/dark cycle at $20-24^{\circ} \mathrm{C}$. Following acclamitization to their diet and water which they had access to ad libitum, they were randomly divided into 4 groups of eight rats each. Group I served as the control (C). Group 2 served as the honey group (Honey); Group 3 served as the negative control or cigarette smoke-exposed (CS) while Group 4 was the treatment group or honeytreated plus CS-exposed (Honey+CS).

Rats in control and CS groups received distilled water (0.5 mL/day) while rats in Honey and Honey+CS groups received honey (1.2 g/kg body weight/day) by oral gavage with distilled water as the carrier. Rats in CS and Honey+CS groups were exposed to cigarette smoke in a chamber for 8 minutes (3 times/day) (22). Water and food were given to the rats ad libitum. The study was approved by the animal ethical committee of the Universiti Sains Malaysia and the animals were handled in line with the Guide for the Care and Use of Laboratory Animals as given by the National Institute of Health. Following 13 weeks of treatment, the rats were anesthetized with sodium thiopental and euthanized. Their lungs were harvested and a portion was used for histology study. For each of the remaining portions, the trachea was tied to a syringe containing $10 \mathrm{ml} 0.9 \% \mathrm{NaCl}$, sucked out after $1 \mathrm{~min}$, transferred to a bottle and infused with $10 \mathrm{ml} 0.9 \% \mathrm{NaCl}$. Thereafter, it was sucked out again and the bronchoalveolar lavage fluid (BALF) was transferred to another bottle and stored at $-80^{\circ} \mathrm{C}$ until it was analyzed for the lung surfactants-phosphatidyl choline, phosphatidyl glycerol and phosphatidyl choline/phosphatidyl glycerol ratio (using Thin Layer Chromatography and Malachite Green assay kit), surfactant protein A levels respectively using (ELISA kit).

\section{Histology}

A section of the lungs from each of the rats was cut, fixed in $10 \%$ formalin and histology assays were carried out following the method of Dunn (24) and Parveen et al (25) respectively. For hematoxylin and eosin (H\&E) staining, 5- $\mu \mathrm{m}$-cut sections of the lungs were stained in hematoxylin for $5 \mathrm{~min}$ and washed with water. Thereafter, 
they were stained in eosin for 2 min, dehydrated with alcohol, passed through xylene 1 and 2 and mounted for viewing under a microscope. The average number of alveolar macrophages containing carbon particles per field at 40x magnification was analysed. A total of 5 fields per slide for each rat was assessed and counted in a blinded fashion.

\section{Physical analysis of Tualang honey Evaluation of colour intensity}

Tualang honey was diluted to $50 \%(\mathrm{w} / \mathrm{v})$ with warm distilled water $\left(40-50^{\circ} \mathrm{C}\right)$ and vortex-mixed for $5 \mathrm{~min}$. Thereafter, it was filtered $(0.45 \mu \mathrm{m}$ pore size) to eliminate large particles. Colour intensity of the honey was calculated as the difference between spectrophotometric absorbance at 450 and $720 \mathrm{~nm}$ respectively. This measurement was done in triplicate and the colour intensity was expressed as mili-absorbance unit (mAU) (26).

\section{Evaluation of $\mathrm{pH}$}

Ten grams of honey were dissolved in $75 \mathrm{~mL}$ of deionized water in a beaker. Thereafter, the $\mathrm{pH}$ of the honey solution was measured using a $\mathrm{pH}$ meter (27).

\section{Determination of the moisture content}

Briefly, a weighed amount of honey sample was dried in an oven at $105^{\circ} \mathrm{C}$ for $3 \mathrm{hrs}$ or until a constant weight was achieved. Samples were analysed in triplicate and the moisture content was calculated as a percentage.

\section{Preparation of honey extract for screening for phenolic compounds}

Natural phenolic compounds that are present in the honey were extracted using ethyl acetate to separate them from dominant sugars as reported earlier with some modifications $(28,29)$. Briefly, $10 \mathrm{~g}$ of honey was dissolved in $10 \mathrm{~mL}$ of deionized water. Then $10 \mathrm{~mL}$ of ethyl acetate was added and the setup was mixed well in a rotary shaker for $10 \mathrm{~min}$. The solution was centrifuged at 2500 $\mathrm{rpm}$ at $4^{\circ} \mathrm{C}$ for $10 \mathrm{~min}$ and the supernatant was transferred into a tube. This ethyl acetate extraction procedure was repeated twice. The extracts were combined and dried under a nitrogen flow at room temperature. The dried extract was then dissolved in $0.4 \mathrm{~mL}$ of methanol and screened for the phenolic profile using high performance thin layer chromatography (HPTLC).

\section{Screening for the presence of phenolic com-} pounds:

The screening for the presence of phenolic compounds was performed twice and divided into two phases: phase 1 was without the standards whereas phase 2 was with the standards.

\section{Phase 1}

Briefly, $2 \mu \mathrm{L}$ of honey extract was spotted on a thin layer chromatography (TLC) plate $(10 \mathrm{~cm}$ $\mathrm{x} 10 \mathrm{~cm})$ pre-coated with silica gel at the starting position. The phenolic compounds in the honey extract migrated through this thin sorbent layer (stationary phase). The solvent mixtures, n-hexane/ ethyl acetate $(4: 6, \mathrm{v} / \mathrm{v})$ were used as the mobile phase to separate these compounds. This mobile phase solvent ratio was selected as it could produce the highest number of separated compounds on the TLC plate after optimization was carried out using different ratios of solvents. The movement of the compounds depends on their different affinities to these two phases (30). The phenolic compounds were detected as coloured spots after spraying the plates with $1 \%$ 2-aminoethyl diphenylborinate solution (dissolved in methanol). This reagent reacts with phenolic compounds which became visible as blue, green, yellow and orange fluorescent spots or bands. After $5 \mathrm{~min}$, the plate was visualized under ultraviolet (UV) light at $366 \mathrm{~nm}$ using a TLC visualizer (29).

Another chromatogram was prepared and sprayed with $0.02 \%$ 1,1-diphenyl-2-picrylhydrazyl (DPPH) radical solution (prepared in ethanol) to assess the in vitro antioxidant property of the compounds. The DPPH radical reacts with the compounds that have antioxidant activity. In this reaction, the purplecoloured DPPH radical turned into yellow-coloured DPPH spots. After an hour, the chromatogram was examined under white light (29).

\section{Phase 2}

In this phase, $2 \mu \mathrm{L}$ of honey extract and 1 $\mu \mathrm{L}$ of phenolic standards such as benzoic acid, 
caffeicacid, gallic acid, luteolin, trans-cinnamic acid and vanillic acid ( $1 \mathrm{mg} \mathrm{mL}^{-1}$ in methanol) were spotted on a TLC plate $(10 \mathrm{~cm} \mathrm{x} 10 \mathrm{~cm})$ pre-coated with silica gel. Another plate was also prepared with honey extract and phenolic standards $(1 \mathrm{mg}$ $\mathrm{mL}^{-1}$ in methanol) such as catechin, hesperitin, kaempferol, naringenin, naringin, p-coumaric acid and syringic acid. The plates were developed, sprayed with $1 \%$ 2-aminoethyl diphenylborinate solution and visualized under UV light at $366 \mathrm{~nm}$.

\section{Statistical Analysis}

Statistical analysis using SPSS version 24 was carried out. Data are expressed as mean \pm SEM. One-way analysis of variance (ANOVA) was used for data analysis, followed by Tukey posthoc test. $P$ value $<0.05$ was considered statically significant.

\section{Results}

Table 1 shows the results of the physical properties of the Tualang honey that was analyzed in this study. As shown in the Table, the colour intensity of the Tualang honey was obtained as $272.75 \mathrm{mAU}$; the $\mathrm{pH}$ was obtained as 3.43 while the moisture content was obtained as $17.38 \%$.

Table 1: Physical properties of Tualang honey

\begin{tabular}{lcc}
\hline Parameters & $\begin{array}{c}\text { Tualang } \\
\text { honey }\end{array}$ & $\begin{array}{c}\text { Criteria } \\
\text { for quality } \\
\text { honey* }\end{array}$ \\
\hline Colour intensity (mAU) & $272.75(1.50)$ & - \\
$\mathrm{pH}$ & $3.43(0.00)$ & - \\
Moisture (\%) & $17.38(0.44)$ & $<20$ \\
\hline $\begin{array}{l}\text { Data are expressed as mean (SEM), } \mathrm{n}=3 . \mathrm{mAU}, \text { mili-absorbance unit; } \\
{ }^{*} \text { Codex Alimentarius Commision (35) }\end{array}$
\end{tabular}

Figure 1A shows the profile of the chromatogram of the Tualang honey extract (Phase 1 screening) after it was sprayed with 2-aminoethyl diphenylborinate and viewed under UV light at $366 \mathrm{~nm}$. The phenolic compounds in the extract presented as blue, green, yellow and orange bands. A total of 18 coloured bands were seen in the chromatogram which indicates the presence of 18 unidentified phenolic compounds in the extract.

Figure 1B shows the profile of the chromatogram of Tualang honey extract after it was sprayed with DPPH radical and viewed under white light. The presence of compounds that have antioxidant activity became visible as yellow bands.

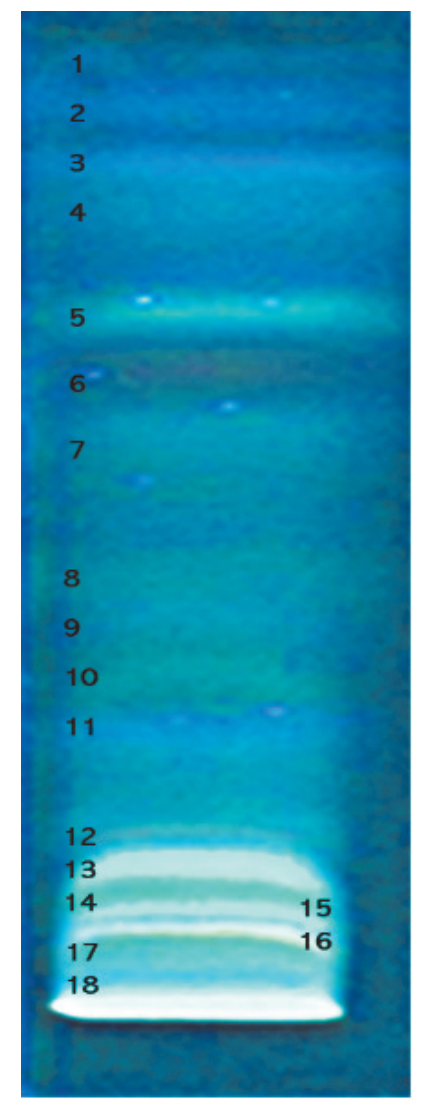

A

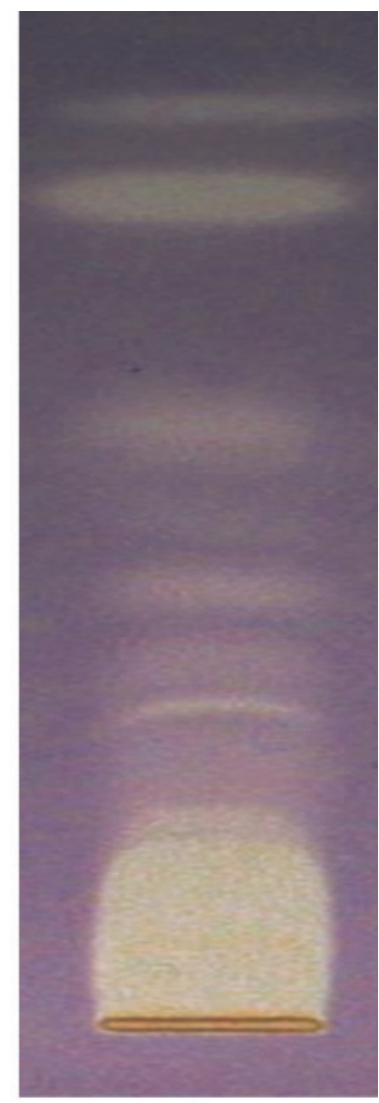

B
Figure 1: Chromatogram of Tualang honey extract when sprayed with 2-aminoethyl diphenylborinate and viewed under UV light $366 \mathrm{~nm}$ (A) and when sprayed with DPPH radical and viewed under white light (B). Chromatogram A shows the presence of 18 unidentified phenolic compounds which became visible as blue, green, yellow and orange bands. Chromatogram B shows the presence of compounds that have antioxidant activity which became visible as yellow bands

Figure 2 shows the findings on the screening of the phenolic compounds in the Tualang honey extract (Phase 2 screening). The chromatogram of Tualang honey extract and the phenolic standards, when they were sprayed with 2-aminoethyl diphenylborinate and viewed under UV light at $366 \mathrm{~nm}$, showed the presence of five identified phenolic compounds namely: caffeic acid, gallic acid, luteolin, kaempferol and $p$-coumaric acid in the honey extract. 

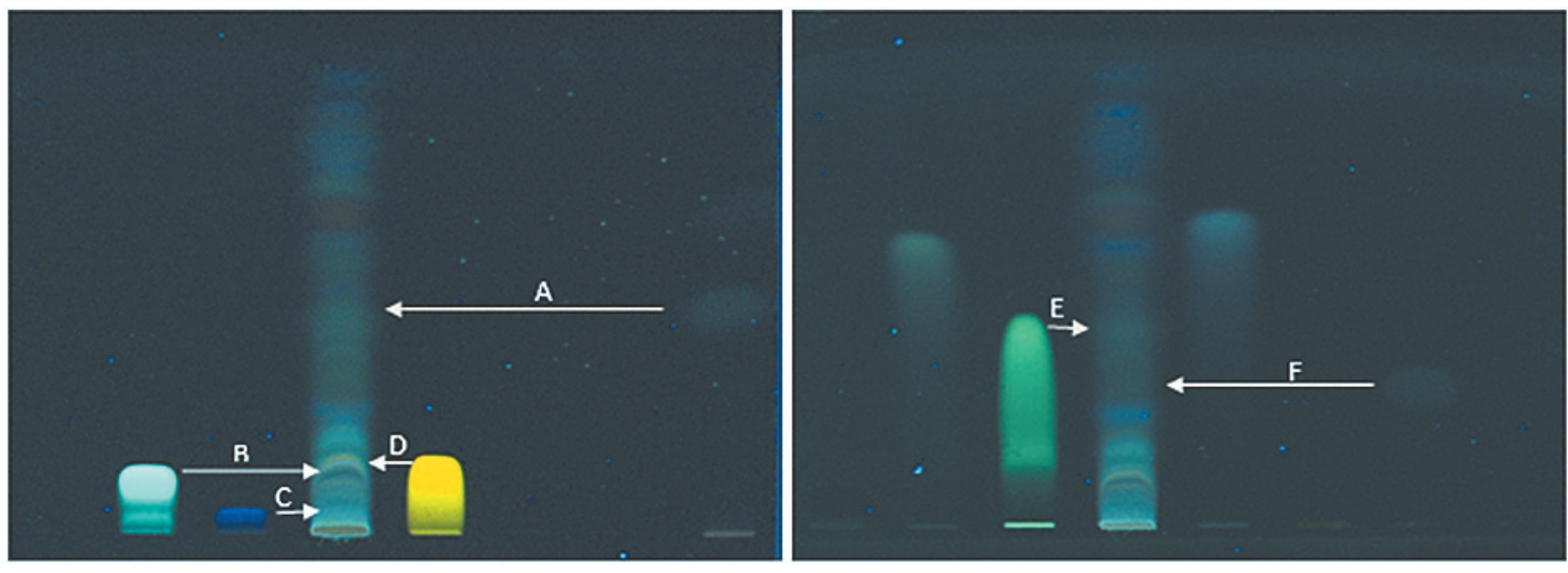

$\begin{array}{llllllll}1 & 2 & 3 & 4 & 5 & 6 & 7 & 8\end{array}$

910

$1011 \quad 12$

$13 \quad 14 \quad 15$

16

Figure 2: Chromatogram of Tualang honey extract and standards (tracks 1 - 16) when sprayed with 2-aminoethyl diphenylborinate and viewed under UV light $366 \mathrm{~nm}$. Arrows show the presence of 5-hydroxymethyl-2-furfural (HMF; A) and phenolic compounds such as caffeic acid (B), gallic acid (C), luteolin (D), kaempferol (E) and p-coumaric acid (F) in the honey extract. 1, benzoic acid; 2, caffeic acid; 3, gallic acids; 4 and 12, Tualang honey extract; 5, luteolin; 6, trans-cinnamic acid; 7, vanillic acid; 8, HMF; 9, catechin; 10, hesperitin; 11, kaempferol; 13, naringenin; 14, naringin 15, p-coumaric acid; and 16, syringic acid

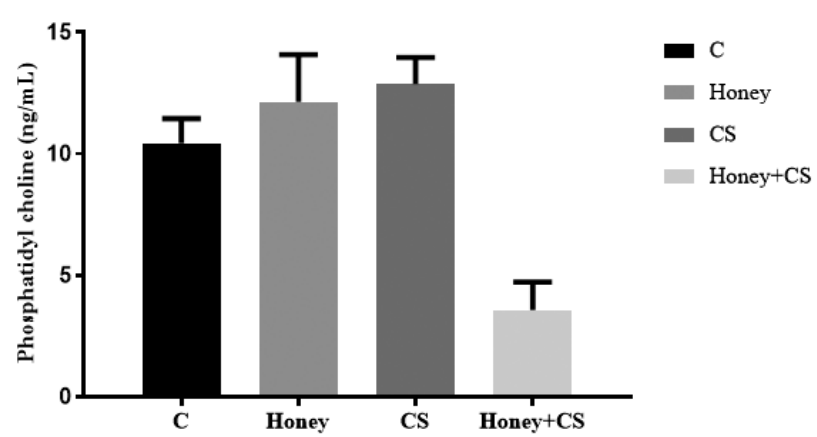

Figure 3: Phosphatidyl choline concentrations of rats. Data are expressed as mean \pm SEM. $n=8 /$ group. No significant difference were found among all the groups (One-way ANOVA). C: Control, CS: Cigarette smoke

Figure 3 presents the phosphatidyl choline concentrations of the rats that were investigated. As shown in the figure, there were no significant differences $(P>0.05)$ in the phosphatidyl choline concentrations of all the rats in the respective groups.

The phosphatidyl glycerol concentrations of the rats that were studied are shown in Figure 4. As shown in the figure, there were also no significant differences $(P>0.05)$ in the phosphatidyl glycerol concentrations of all the rats in the respective groups.

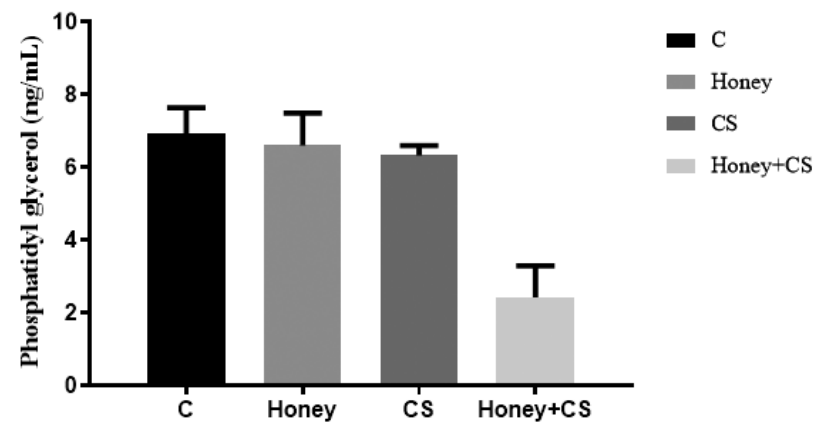

Figure 4: Phosphatidyl glycerol concentrations of rats. Data are expressed as mean \pm SEM. $n=8$ /group. No significant difference were found among all the groups (One-way ANOVA). C: Control, CS: Cigarette smoke

Figure 5 shows the phosphatidylcholine/ phosphatidylglycerol ratio of the rats that were investigated in this study. As shown in the Figure, the $\mathrm{PC} / \mathrm{PG}$ ratio of the normal rats administerd honey did not differ significantly $(P>0.05)$ from that of the control. In contrast, the $\mathrm{PC} / \mathrm{PG}$ ratio of the rats in the CS group was significantly higher $(P<0.05)$ than the control group. However, administration of Tualang honey to the rats exposed to cigarette smoke resulted in decreased $(P<0.05)$ levels of their PC/PG ratio compared to the CS group. 


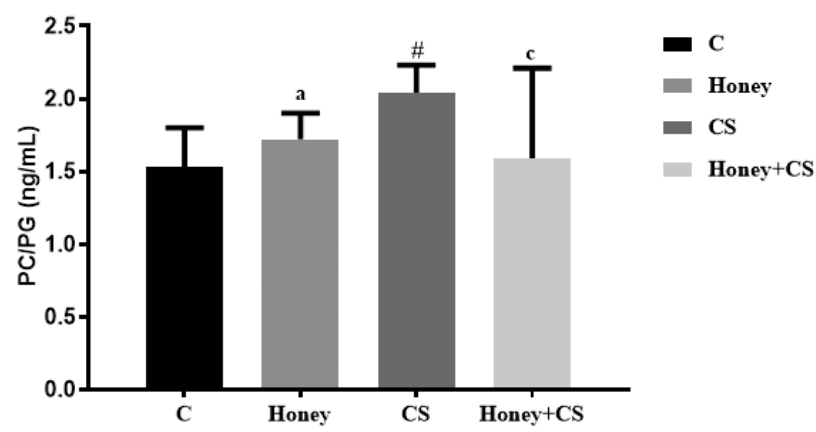

Figure 5: $\mathrm{PC} / \mathrm{PG}$ ratio of rats exposed to cigarette smoke. $\mathrm{n}=8$ / group; ${ }^{a} \mathrm{P}>0.05$ as compared to $\mathrm{C}$ group; $\mathrm{P}<0.05$ as compared to $\mathrm{C}$ group; ${ }^{\mathrm{C}} \mathrm{P}<0.05$ as compared to $\mathrm{CS}$ group (One-way ANOVA followed by Tukey's post hoc test). C: Control, CS: Cigarette smoke, PC: Phosphatidylcholine, PG: Phosphatidylglycerol

Figure 6 shows the surfactant protein A concentrations of the rats that were studied. As presented in the figure, there were no significant differences $(P>0.05)$ in the surfactant protein A concentrations of all the rats in the respective groups.

Figure 7 shows the histology of the lungs of the rats that were investigated in this study while the quantitative data that were collected on the number of alveolar macrophages containing carbon particles are presented in Table 2. As seen in the figure presented, the $\mathrm{C}$ group had no visible alveolar macrophages containing carbon particles (Figure 7[A]). Similarly, histology of the lungs of the normal rats administered Tualang honey

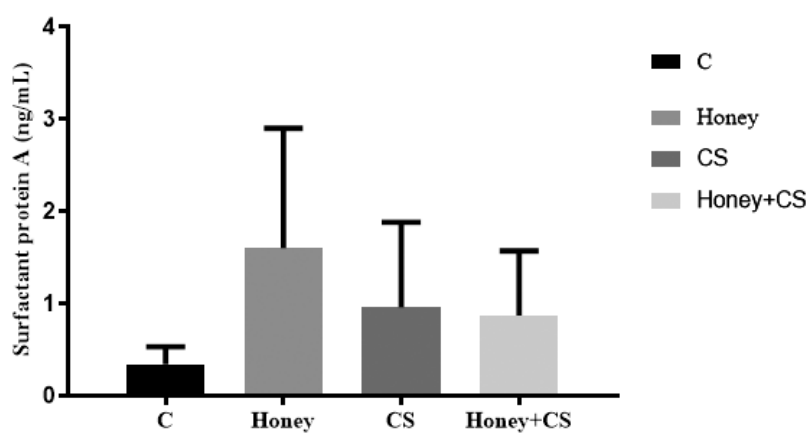

Figure 6: Surfactant Protein A concentrations of rats. Data are expressed as mean \pm SEM. $n=8 /$ group. No significant difference were found among all the groups (One-way ANOVA). C: Control, CS: Cigarette smoke

showed no visible alveolar macrophages containing carbon particles (Figure 7[B]). These findings were corroborated with the quantitative data in Table 2. In contrast, histology of the lungs of the CS group revealed the presence of many alveolar macrophages containing carbon particles (Figure $7[\mathrm{C}]$ ) compared to C, Honey and Honey + CS groups (Figure 7[D]). Quantitative data showed significant increased number of alveolar macrophages containing carbon particles in CS group compared to $\mathrm{C}$ and Honey groups. However, the number of alveolar macrophages containing carbon particles was significantly decreased in the cigarette smoke exposed rats co-administered with Tualang honey (Honey+CS group) compared to CS group although it was significantly increased compared to $\mathrm{C}$ and Honey groups (Table 2).
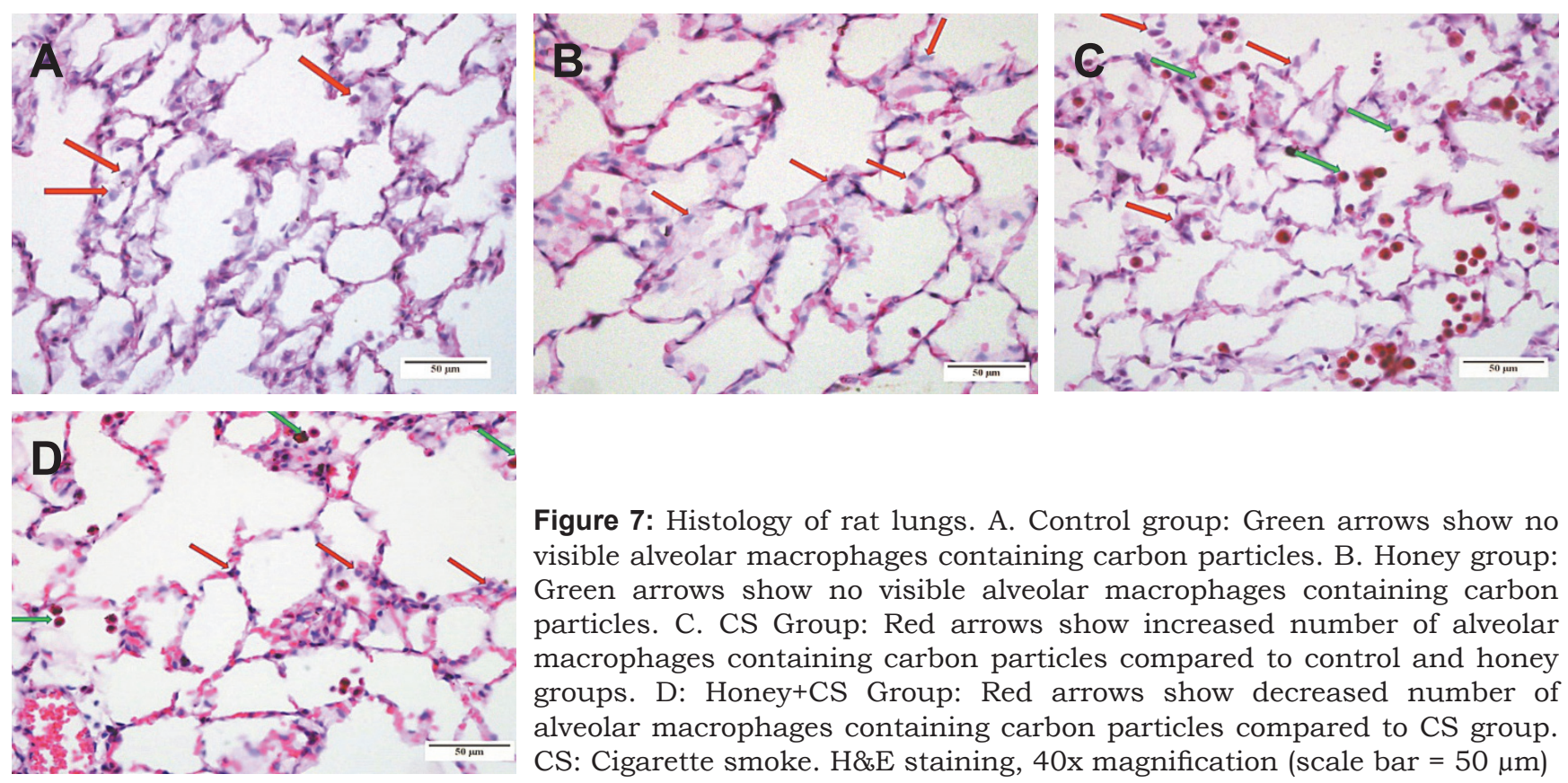

Figure 7: Histology of rat lungs. A. Control group: Green arrows show no visible alveolar macrophages containing carbon particles. B. Honey group: Green arrows show no visible alveolar macrophages containing carbon particles. C. CS Group: Red arrows show increased number of alveolar macrophages containing carbon particles compared to control and honey groups. D: Honey+CS Group: Red arrows show decreased number of alveolar macrophages containing carbon particles compared to CS group. CS: Cigarette smoke. H\&E staining, 40x magnification (scale bar $=50 \mu \mathrm{m}$ ) 
Table 2: Number of alveolar macrophages containing carbon particles

\begin{tabular}{|c|c|}
\hline Groups & $\begin{array}{c}\text { Number of alveolar } \\
\text { macrophages } \\
\text { containing carbon } \\
\text { particles }\end{array}$ \\
\hline $\mathrm{C}$ & $0.00 \pm 0.00$ \\
\hline Honey & $0.00 \pm 0.00$ \\
\hline $\mathrm{CS}$ & $16.97 \pm 0.88^{\mathrm{a}, \mathrm{b}}$ \\
\hline Honey+CS & $5.83 \pm 0.30^{a, b, c}$ \\
\hline
\end{tabular}

\section{Discussion}

Colour intensity of honey can help in classifying different types of honey and it gives an idea about its quality. In fact, colour intensity of honey was previously reported (30) to correlate with its total phenolic contents.

The values we obtained in this study for the colour intensity of the Tualang honey was similar to the values that were reported for Chicory honey (26), suggesing that our Tualang honey may be rich in phenolic constituents.

Honey has been reported to have an acidic $\mathrm{pH}$ which helps it in promoting wound healing and also inhibiting the growth of microorganisms (32). The value that was obtained for the $\mathrm{pH}$ of Tualang honey was consistent with the values that were reported for floral or blossom honeys (27) and honeys from other countries $(33,34,35)$. The moisture content of honey is one of the criteria that determines its shelf life and ability to resist spoilage by microorganisms (32). The Codex Alimentarius Commission (36) gave a standard for water in good and natural honeys (Table 1). Going by this, data that were obtained for the moisture content of Tualang honey make the Tualang honey analyzed to be good honey apart from other properties of this Tualang honey (such as glucose, fructose, maltose, sucrose and 5-hydroxymethyl-2-furfural) that also fell within the standard that was given by the Codex Alimentarius Commission (36) as previously reported (22).

Phenolic compounds have been suggested to be the main antioxidants that contribute to the antioxidant properties of honey (26) and this informed our screening and separation of the phenolic compounds in Tualang honey using
HPTLC. Most of the phenolic compounds that appeared as coloured bands (in Phase 1 screening) were found to scavenge DPPH radical as seen from the yellow bands of the chromatogram (when it was sprayed with DPPH radical), indicating the antioxidant properties of the phenolic compounds in Tualang honey. This further affirms our previous reports on the antioxidant properties of Tualang honey (22).

The number of phenolic compounds in Tualang honey that were separated and identified by HPTLC was higher as compared to Buckwheat and Chilean honeys which were reported to have 4 unknown phenolic compounds (29). This difference could be due to the different floral sources of honeys as floral source is one of the important factors that affect the composition of honey (37). The other plausible reason might be due to the different solvent system that was used as mobile phase to separate those compounds. The movement of the compounds depends on their different affinities to the stationary and mobile phases. In the present study, a solvent, $\mathrm{n}$-hexane/ethyl acetate $(4: 6, \mathrm{v} / \mathrm{v})$ was used to separate the compounds in Tualang honey while another solvent, acetonitrile/water $(87: 13, \mathrm{v} / \mathrm{v})$ was used to separate the compounds in Buckwheat and Chilean honeys (29). This study confirmed the presence of phenolic compounds in Tualang honey and this chromatogram could be used as HPTLC fingerprint of this Tualang honey for identification and comparison with other types of honeys.

In this study, phospholipids were measured by the phosphatidyl choline and phosphatidy glycerol concentrations of the rats as the later form the hydrophilic and hydrophobic constituents of phospholipids that in turn act as the major components of lung surfactants. As seen in this study, the phosphatidylcholine and phosphatidyl glycerol concentrations of the normal rats administered Tualang honey did not differ from that of the control, suggesting that the administered honey had no impact on the phosphatidylcholine and phosphatidyl glycerol concentrations of the rats. Furthermore, exposure to cigarette smoke appeared not to affect the phosphatidylcholine and phosphatidyl glycerol concentrations of the rats as seen from the non significant changes in the phosphatidyl choline and phosphatidyl glycerol concentrations of the rats exposed to cigarette smoke when compared to the control. 
When the phosphatidylcholine/phosphatidylglycerol ratio of the rats was determined, Tualang honey did not also significantly affect this ratio, indicating that it did not negatively impact on the distribution of these phospholipids in the lungs of these groups of rats. On the contrary, exposure to cigarette smoke was found to alter the PC/PG ratio of the rats. Its noteworthy that these phospholipids form essential components of biological membranes and their alteration could lead to increased membrane permeability and tissue damage. Studies have also shown that cigarette smoke contains some free radicals and the soot that arises from cigarette smoke attracts neutrophils to the site which releases more free radicals, leading to peroxidation of these lipids, all of which can result to lung damage (38). Cigarette smoke possibly interferred with the distribution of the phospholipids in the membranes surrounding the lungs of the rats that were exposed to it which led to the increased PC/PG ratio of these rats. Tualang honey demonstrated the ability to protect lung surfactants and biological membranes surrounding the lungs from toxicity of cigarette smoke as seen from the normalization of the PC/PG ratio of the cigarette smoke exposed rats co-administered this honey.

To futher investigate the effect of Tualang honey on lung surfactants exposed to cigarette smoke, surfactant protein A concentration of the rats exposed to cigarette smoke and the effect of administration of Tualang honey was measured. The non significant changes in the surfactant protein A concentrations of the rats in the respective groups as obtained in this study, suggests that exposure to cigarette smoke may not have had any negative effect on the surfactant protein A concentrations of these rats. The implication is that the potential targets for cigarette smoke in the lungs are the distribution of phospholipids.

To further confirm the effect of exposure of lung surfactants to cigarette smoke and the protective action of Tualang honey, a histological assay was performed. Findings from this study showed a reduced number of type II pneumocytes but increased number of alveolar macrophages in the cigarette smoke group. It is possible that the reduced number of type II pneumocytes but increased number of alveolar macrophages in the cigarette smoke group may have exercabated or enhanced the alteration in the PC/PG ratio of their lung surfactants. We therefore postulate that cigarette smoke exerts its deletrious action on the lungs by altering the PC/PG ratio, decreasing the Type II pneumocytes levels and increasing alveolar macrophage levels.

The histology of the lungs of the cigarette smoke exposed rats treated with Tualang honey as seen in this study was found to be similar to the control group with reduced number of alveolar macrophage as compared to cigarette smoke group. These findings which corroborated the results of other assays we performed, therefore indicate the promising potentials of Tualung honey in protecting lung surfactants from the deleterious action of cigarette smoke which may be associated with its antioxidant phenolic compounds as these phenolic compounds have been reported to protect the lungs from cigarette smoke associated lung injury (39).

This study revealed that honey has some protective effects against the cigarette smokeinduced changes in lung surfactant profiles and pneumocytes in male rats.

\section{Acknowledgement}

The study was funded by the Universiti Sains Malaysia Short term Grant (304/PPSP/6131586). The authors declare no conflicts of interest.

\section{References}

1. Avery ME. Surfactant deficiency in hyaline membrane disease: the story of discovery. Am J Resp Crit Care Med 2000; 161: 1074-5.

2. Nkadi PO, Merritt TA, Pillers DM. An overview of pulmonary surfactant in the neonate: genetics, metabolism, and the ole of surfactant in health and disease. Mol Genet Metab 2009; 97(2): 95-101.

3. Miller BE, Hook GER. Hypertrophy and hyperplasia alveolar type II cells in response to silica and other pulmonary toxicants. Environ Health Perspect 1990; 85: 15-23.

4. Jobe AH, Ikegami M. Surfactant for acute respiratory distress syndrome. Adv Intern Med 1997; 42: 203-30.

5. Chi C, He B, Zhang H, Tang X. Therapeutic effects of pulmonary surfactant on smoking-induced lung injury in rats, an experimental study. Zhonghua Yi Xue Za Zhi 2002; 82: 1060-2.

6. Scott JE. The pulmonary surfactant: impact 
of tobacco smoke and related compounds on surfactant and lung development. Tob Induc Dis 2004; 2(1): 3-25. doi: 10.1186/1617-9625-2-1-3

7. Dunn A, Zeine L. Health effects of exposure to environmental tobacco smoke. California Environmental Protection Agency. Tob Control 1997; 6: 346-53.

8. Janson C. The effect of passive smoking on respiratory health in children and adults. Int $\mathrm{J}$ Tuberc Lung Dis 2004; 8: 510-6.

9. Jha P. Avoidable global cancer deaths and total deaths from smoking. Nat Rev Cancer 2009; 9: 655-64.

10. Mathieu CM, Maxime L, Jean-Christophe B, et al. Impact of cigarette smoke on the human and mouse lungs: a gene-expression comparison study. Plos One 2014; 9: e92498 doi: 10.1371/ journal.pone.0092498

11. Subramaniam S, Bummer P, Gairola CG. Biochemical and biophysical characterization of pulmonary surfactant in rats exposed chronically to cigarette smoke. Fundam Appl Toxicol 1995; 27 : 63-9.

12. Schmekel B, Khan AR, Linden M, Wollmer P. Recoveries of phosphatidylcholine and alveolar macrophages in lung lavage from healthy light smokers. Clin Physiol 1991; 11: 431-8.

13. Putman E, van Golde LMG, Haagsman HP. Toxic oxidant species and their impact on the pulmonary surfactant system. Lung 1997; 175: 75103.

14. Karla LM, Daniele CC, Maria ACD, et al. Respiratory immunohistochemical study in rats exposed to cigarette smoke and alcohol. Acta Cir Bras 2015; 30: 178-85.

15. Turkmen N, Sari F, Poyarazoglu ES, Velioglu YS. Effects of prolonged heating on antioxidant activity and colour of honey. Food Chem 2005; 95: 653-7.

16. Samarghandian S, Tahereh F, Fariborz S. Honey and health: a review of recent clinical research. Pharmacogn Res 2017; 9: 121-7.

17. Estevinho L, Pereira AP, Moreira L, Dias LG, Pereira E. Antioxidant and antimicrobial effects of phenolic compounds extracts of Northeast Portugal honey. Food Chem Toxicol 2008; 46: 3774-9.

18. Erejuwa OO, Sulaiman SA, Ab Wahab MS. Honey: a novel antidiabetic agent. Int $\mathrm{J}$ Biol Sci 2012; 8: 913-34.

19. Khalil I, Moniruzzaman M, Boukraâ L, et al. Physicochemical and antioxidant properties of Algerian honey. Molecules 2012; 17: 11199-215.
20. Attia WY, Gabry MS, El-Shaikh KA, Othman GA. The anti-tumor effect of bee honey in Ehrlich ascite tumor model of mice is coincided with stimulation of the immune cells. Egypt J Immunol 2008; 15: 169-83.

21. Ahmed S, Othman NH. Honey as a potential natural anticancer agent: a review of its mechanisms. Evid Based Complement Alternat Med 2013; 2013: e829070. doi: 10.1155/2013/829070

22. Mohamed M, Sulaiman SA, Jaafar H, Sirajudeen KNS. Antioxidant protective effect of honey in cigarette smoke-induced testicular damage in rats. Int J Mol Sci 2011; 12: 5508-21.

23. Pasupuleti VR, Kumara TK, Naguib S, Siew HG. Biological and therapeutic effects of honey produced by honey bees and stingless bees: a comparative review. Rev Bras Farmacogn 2016; 26: 657-64.

24. Dunn WL. Handbook of histopathological and histochemical techniques. 3rd ed. Redwood: Bun, Trowbridge, Esher, 1974: 10-15.

25. Parveen K, Uma B, Shrirang J. Fenugreek seed extract inhibit fat accumulation and ameliorates dyslipidemia in high fat diet-induced obese rats. BioMed Res Int 2014; 2014: e606021(1-11). doi: $10.1155 / 2014 / 606021$

26. Berretta G, Granata P, Ferrero M, Orioli M, Facino RM. Standardization of antioxidant properties of honey by combination of spectrophotometric/fluorometric assays and chemometrics. Anal Chim Acta 2005; 533: 185-91.

27. Bogdanov S. Characterization of antibacterial substances in honey. Lebensm Wiss Technol 1984; 17: 74-6.

28. Tuberoso CIG, Bifulco E, Jerković I, Caboni P, Cabras P, Floris I. Methyl syringate: a chemical marker of asphodel (Asphodelus microcarpus Salzm. et Viv.) monofloral honey. J Agric Food Chem 2009; 57: 3895-900.

29. Van Den Berg AJ, Van den Worm E, Van Ufford $\mathrm{HC}$, et al. An in vitro examination of the antioxidant and anti-inflammatory properties of buckwheat honey. J Wound Care 2008; 17: 172-4.

30. Meda A, Lamien CE, Romito M, Millogo J, Nacoulma OG. Determination of the total phenolic, flavonoid and proline contents in Burkina Fasan honey, as well as their radical scavenging activiity. Food Chem 2005; 91: 571-7.

31. Reich E, Schibli A, Debatt A. Validation of high-performance thin-layer chromatographic methods for the identification of botanicals in a cGMP environment. J AOAC Int 2008; 91: 13-20. 
32. Eleazu CO, Iroaganachi MA, Eleazu KC, Okoronkwo JO. Determination of the physico-chemical composition, microbial quality and free radical scavenging activities of some commercially sold honey samples in Aba, Nigeria: 'The effect of varying colours. Int $\mathrm{J}$ Biomed Res 2013; 4: 32-41.

33. Abselami A, Tahani A, Sindic M, Fauconnier ML, Bruneau E, Elbachiri A. physicochemical properties of some honeys produced from different flora of Eastern Morocco. J Mater Environ Sci 2018; 9: 879-86.

34. Sohaimy SAE, Masry SHD, Shehata MG. Physicochemical characteristics of honey from different origins. Ann Agric Sci 2015; 60: 279-87.

35. Ahma A, Seif EAM, Mohammad JA, Nuru, A. Comparison of physicochemical properties and effects of heating regimes on stored Apis mellifera and Apis florea honey. Saudi J Biol Sci 2017; 26: 845-8.

36. Codex Alimentarius. Codex standard for honey. Rome : FAO, 2001: Alinorm: 19-26.

37. Gheldof N, Wang XH, Engeseth NJ. Identification and quantification of antioxidant components of honeys from various floral sources. $\mathrm{J}$ Agric Food Chem 2002; 50: 5870-7.

38. Vasudevan DM, Sreekumari S, Vaidyanathan, K. Textbook of biochemistry for medical students. 7th ed. New Delhi, India : Jaypee Brothers Medical Publishers Pvt. 2013.

39. Bao MJ, Shen J, Jia YL, et al. Apple polyphenol protects against cigarette smoke-induced acute lung injury. Nutrition 2013; 29: 235-43.

\title{
KEMIČNA SESTAVA MEDU TUALANG IN NJEGOV VPLIV NA POVRŠINSKO AKTIVNE SNOVI V PLJUČIH TER HISTOLOGIJO PLJUČ SAMCEV PODGAN, IZPOSTAVLJENIH CIGARETNEM DIMU
}

\author{
C. Eleazu, A. C. Romli, W. F.W. A. Rahman, Z. Zakaria, Z. A. Othman, M. Mohamed
}

\begin{abstract}
Povzetek: Raziskava poroča o kemijski sestavi medu Tualang in njegovem vplivu na površinsko aktivne snovi v pljučih ter histologijo pljuč samcev podgan, izpostavljenih cigaretnemu dimu. V študiji so uporabili 32 odraslih podgajih samcev seva Sprague-Dawley, ki so bili naključno razdeljeni v 4 skupine po osem podgan: kontrolna skupina, skupina, ki je uživala med s prehrano (Honey), skupina, ki je bila izpostavljena cigaretnemu dimu (CS) in skupina, ki je bila izpostavljena cigaretnemu dimu ter je uživala med (Honey+CS). Podgane v kontrolnih skupinah in skupinah CS so dobile destilirano vodo (0,5 ml/dan), podgane $v$ skupinah Honey in Honey + CS pa peroralno med (1,2 g/kg telesne teže/dan). Poleg tega so bile podgane $v$ skupinah CS in Honey + CS izpostavljene v komori cigaretnemu dimu trikrat na dan po 8 minut. Izpostavljenost podgan cigaretnemu dimu je bistveno spremenila razmerje fosfatidilholina/fosfatidilglicerola (PC/PG), ne pa tudi ravni površinsko aktivne snovi $A$ v pljučih in ni vplivala na število alveolarnih makrofagov, ki vsebujejo ogljikove delce. Uporaba medu Tualang pri podganah, izpostavljenih cigaretnemu dimu, je povzročila spremembo večine opazovanih parametrov, katerih rezultati so bili potrjeni s histološko preiskavo. Intenzivnost barve medu je bila 272,75 enote mili-absorbance, $\mathrm{pH} 3,43$, vsebnost vlage v medu pa je bila $17,38 \%$. Presejalni test na fenolne spojin v medu Tualang s tankoplastno kromatografijo je pokazal prisotnost 18 spojin, od katerih jih je bilo 5 prepoznanih kot spojine z močno in vitro antioksidativno sposobnostjo, kot je razvidno iz njihove sposobnosti odstranjevanja radikala 2,2-difenil-1-pikril hidrazila. Študija je pokazala obetavne potenciale medu Tualung pri zaščiti pljučnih površinsko aktivnih snovi pred škodljivim delovanjem cigaretnega dima, kar je lahko povezano z njegovimi antioksidativnimi fenolnimi spojinami.
\end{abstract}

Kjučne besede: med tualang; surfaktant; inhalacijska toksikologija; fenoli 